\title{
PENGGUNAAN MODEL CONCEPT SENTENCE DALAM PEMBELAJARAN MENULIS PARAGRAF
}

\author{
${ }^{1}$ Suhartini, ${ }^{2}$ Suhardi Abdullah, ${ }^{3}$ Pamuti \\ ${ }^{1}$ Guru SDN 20 Halmahera Barat, ${ }^{2,3}$ Dosen PGSD FKIP Unkhair \\ Email: \\ suhartini_80@yahoo.co.id \\ abdullahsuhardi@gmail.com \\ mutipamuti0906@gmail.com
}

\begin{abstract}
The objectives of these research was to developed student's competence of writing a paragraph in using Concept sentence. These Classroom action research held at the 3rd grade of SDN 20 West Halmahera at the year of 2018-2019. The type of this research was classroom action research and consist of two cycles that includes in planning, action, observation and reflection. The technique that used in this research were, observation, interviews and evaluation. The result of this researched concluded that in using concept sentence increased students competence in writing a paragraph proved by some items consisted of (1) concept sentence correctly implemented (2) the setting or placement of the punctuation and letter were correctly (3) the students chosen of words in thir thought based on the key words (4) the interrelation of each sentence in a paragraph was correctly design.
\end{abstract}

Key Words: Improving, concept sentence model, writing paragraph

\section{PENDAHULUAN}

Berhasilnya tujuan pendidikan tergantung pada bagaimana proses belajar mengajar yang dialami oleh siswa. Menciptakan kegiatan belajar mengajar yang mampu menciptakan hasil belajar yang efektif dan inspiratif merupakan tugas dan kewajiban guru. Menurut Naim (2011: 171), penciptaan iklim dan suasana pembelajaran yang inspiratif akan semakin memperkukuh karakter dan sifat inspiratif guru.

Hal yang sama pada pembelajaran menulis yang mempunyai kedudukan yang sangat strategis dalam pendidikan dan pengajaran. Keterampilan menulis harus dikuasai oleh anak sedini mungkin dalam kehidupannya di sekolah (Syafi'i, 1993: 52 dalam Saddhono dan Slamet, 2012: 95).

Menurut Brown (1994: 20) (dalam Saddhono dan Slamet, 2012: 1) pengajar hendaknya mampu menciptakan lingkungan belajar yang dapat memberikan rangsangan atau tantangan sehingga para pelajar tertarik untuk belajar secara aktif. 
Keaktifan pelajar memang sangat diperlukan karena belajar menuntut aktivitas dari diri sendiri, baik mental maupun fisik. Pada masa lalu dalam pembelajaran keterampilan termasuk menulis, para guru hanya bertujuan agar siswa dapat meghasilkan sesuatu sehingga evaluasi juga hanya diarahkan pada hasil keterampilannya itu, yaitu karangannya (Tomkins, 1990: 4) (dalam Saddhono dan Slamet, 2012: 1). Oleh karena itu, seringkali pembelajaran menulis lebih banyak dilakukan dengan memberi tugas-tugas menulis sebagai pekerjaan rumah. Itu menujukkan pembelajaran lebih berioentasi pada produk dan tidak ada bimbingan guru selama proses kreatif tersebut dilalu siswa.

Mengingat kegiatan menulis termasuk suatu keterampilan, yakni keterampilan berbahasa yang sifatnya produktif dipergunakan secara tidak langsung, tidak secara tatap muka dengan orang lain, maka dalam proses pembelajarannya dituntut pula kesempatan bagi siswa untuk berlatih menulis. Dalam kegiatan itu siswa harus terampil memanfaatkan unsur-unsur grafologi, struktur bahasa, atau kosa kata. Keterampilan dalam memanfaatkan unsur-unsur tersebut memang tidak akan datang dengan secara otomatis, melainkan harus melalui latihan dan praktik secara teratur.

Adapun upaya untuk memotivasi minat belajar siswa untuk meningkatkan kualitas proses pembelajaran menulis seperti itu adalah dengan menggunakan model pembelajaran yang menekankan pada aktivitas-aktivitas selama proses menulis tersebut berlangsung, dalam hal ini adalah model consept sentence.

Model consept sentence merupakan salah satu strategi di mana dalam proses pembelajaran siswa dibantu melalui kata-kata kunci tertentu yang disediakan oleh guru yang tentunya berkaitan dengan materi ajar. Siswa akhirnya dapat mengembangkan tulisannya dari kata, kalimat hingga menjadi satu paragraf yang utuh melalui kata kunci-kata kunci yang ada. Hal ini dianggap efektif karena dapat memberikan kemudahan bagi para siswa dalam proses pembelajaran menulis di sekolah, terutama siswa di kelas III SDN 20 Halmahera Barat.

\section{Hakikat Menulis}

Menulis dapat didefinisikan sebagai suatu kegiatan penyampaian pesan (komunikasi) dengan menggunakan bahasa tulis sebagai alat medianya (Suparno dan Yunus, 2003: 3) (dalam Suddhono dan Slamet, 2012: 96). Pesan adalah isi atau muatan yang terkandung dalam suatu tulisan. Tulisan merupakan sebuah simbol atau lambang bahasa yang dapat dilihat dan disepakati pemakainya. Dengan demikian dalam komunikasi tulis paling tidak terdapat empat unsur yang terlibat: penulis sebagai penyampai pesan, isi tulisan, saluran atau media berupa tulisan, 
dan pemaca sebagai penerima pesan. Menulis atau mengarang merupakan kegiatan pengungkapan gagasan secara tertulis (Subana dan Sunarti, 2011: 231).

Suddhono dan Slamet (2012: 96), mengungkapkan pada dasarnya menulis itu bukan hanya berupa melahirkan pikiran atau perasaan saja, melainkn juga merupakan pengungkapan ide, pengetahuan, ilmu, dan pengalaman hidup seseorang dalam bahasa tulis. Oleh karena itu, menulis bukanlah merupakan kegiatan yang sederhana dan tidak perlu dipelajari, tetapi justru dikuasai.

Menulis, di samping sebagai proses, menulis itu juga merupakan suatu kegiatan yang kompleks. Sebagaimana diungkapkan Sri Hastuti (1982: 1) (dalam Suddhono dan Slamet (2012: 97), bahwa kegiatan menulis merupakan kegiatan yang sangat kompleks kerena melibatkan cara berpikir yang teratur dan berbagai persyaratan yang dengan teknik penulisan, antara lain (1) adanya kesatuan gagasan, (2) penggunaan kalimat yang jelas dan efektif, (3) paragraf disusun dengan baik, (4) penerapan kaidah ejaan yang benar, dan (5) penggunaan kosa kata yang memadai.

\section{Pengertian Paragraf}

Paragraf adalah sebagai suatu bentuk pengungkapan gagasan yang terjalin dalam rangkaian beberapa kalimat (Mustakim, 1994: 112). Menurut Kuntarto (2008: 153), paragraf merupakan bagian karangan yang terdiri atas beberapa kalimat yang berkaitan utuh dan padu serta membentuk satu kesatuan pikiran. Di dalam KBBI (Kamus Besar Bahasa Indonesia) paragraf didefinisikan sebagai bagian bab dalam suatu karangan (biasanya mengandung satu ide pokok dan penulisannya dimulai dengan garis baru). Kedua pendapat tersebut di atas dikutip oleh Dalman (2014: 53).

Menurut Mustakim (1994: 120-122) (dalam Dalman, 2014: 65), paragraf pada dasarnya dapat dibedakan menjadi bermacam-macam jenis. Jika dilihat dari fungsinya paragraf dapat dibedakan menjadi tiga jenis, yaitu:

1. Paragraf Pengantar

Paragraf pengantar atau paragraf pembuka merupakan suatu jenis paragraf yang berfungsi untuk mengantarkan pembaca pada pokok-pokok persoalan yang akan dikemukakan. Oleh karena itu, paragraf ini hendaknya dibuat semenarik mungkin agar dapat memikat atau perhatian atau minat pembaca.

2. Paragraf Pengembang

Paragraf pengembang merupakan paragraf yang terletak antara paragraf pengantar dengan paragraf penutup. Fungsinya adalah untuk mengembangkan pokok persoalan yang telah ditentukan. 


\section{Paragraf penutup}

Paragraf penutup merupakan suatu jenis paragraf yang berfungsi mengakhiri karangan atau penutup karangan.

Paragraf dapat pula dibedakan struktur informasinaya, paragraf dapat dibedakan menjadi paragraf deduktif dan paragraf induktik.

1. Paragraf Deduktif

Paragraf deduktif adalah paragraf yang kalimat topiknya terletak di awal paragraf. Perhatikan contoh di bawah ini!

Semangat serta kesungguhan hati guru dalam mengajar dirasakan makin pudar karena kesejahteraan terabaikan. Imbalan yang mereka terima rendah. Gaji mereka sering terlambat dan banyak potongan untuk keperluan yang kadangkadang tidak jelas. Mereka juga tidak memiliki status sosial-ekonomi yang bergengsi.

\section{Paragraf Induktif}

Paragraf induktif adalah paragraf yang kalimat topiknya terletak di akhir paragraf. Perhatikan paragraf di bawah ini!

Siswa yang rajin belajar masih dapat ditemukan di mana-mana, di dalam kota, di pinggir kota, dan di desa. Siswa yang berprestasi tinggi cukup banyak dan dapat ditemukan di mana-mana juga. Tidak sedikit di antara mereka yang memerhatikan dan peduli dengan keadaan lingkungan. Tampaknya, masa depan generasi penerus masih dapat diharapkan.

\section{Pengertian Belajar}

Menurut Gerlach dan Ely dalam bukunya teaching \& media systematic Approach (1971) dalam Arsyad (2011: 3) mengemukakan bahwa "belajar adalah perubahan perilaku, sementara perilaku itu adalah tindakan yang dapat diamati. Dengan kata lain perilaku adalah suatu tindakan yang dapat diamati atau hasil yang diakibatkan oleh tindakan atau beberapa tindakan yang dapat diamati”.

Menurut Gagne dalam Whandi (2007) belajar di definisikan sebagai "suatu proses dimana suatu organisme berubah perilakunya akibat suatu pengalaman". Slameto (2003: 5) menyatakan belajar adalah "suatu proses usaha yang dilakukan seseorang untuk memperoleh suatu perubahan tingkah laku yang baru secara keseluruhan, sebagai hasil pengalamannya sendiri dalam interaksi dengan lingkungannya".

Lebih lanjut Abdillah (2002) dalam Aunurrahman (2010: 35) menyimpulkan bahwa "belajar adalah suatu usaha sadar yang dilakukan oleh individu dalam perubahan tingkah laku baik melalui latihan dan pengalaman yang menyangkut aspek-aspek kognitif, afektif, dan psikomotorik untuk memperoleh tujuan tertentu". 
Dengan demikian dapat disimpulkan Belajar adalah perubahan tingkah laku pada individu-individu yang belajar. Perubahan itu tidak hanya berkaitan dengan penambahan ilmu pengetahuan, tetapi juga berbentuk kecakapan, keterampilan, sikap, pengertian, harga diri, minat, watak, penyesuaian diri. Jadi, dapat dikatakan bahwa belajar itu sebagai rangkaian kegiatan jiwa raga yang menuju perkembangan pribadi manusia seutuhnya.

\section{A. Makna Pembelajaran}

Kata pembelajaran adalah terjemahan dari instruction yang banyak dipakai dalam dunia pendidikan. Menurut La Iru dan Arihi (dalam Prastowo, 2013: 57), secara harfiah pembelajaran berarti proses, cara, perbuatan mempelajari, dan perbuatan menjadikan orang atau makhluk hidup belajar. Pembelajaran merupakan suatu upaya atau proses menciptakan kondisi belajar dalam mengembangkan kemampuan minat dan bakat siswa secara maksimal.

Hal tersebut juga sejalan dengan Undang-undang Nomor 20 Tahun 2013 tentang Sistem Pendidikan Nasional Pasal 1 Ayat 20 yang menjelaskan bahwa pembelajaran adalah proses interaksi antara siswa, guru, dan sumber belajar pada suatu lingkungan belajar.

\section{B. Model Pembelajaran}

Model pembelajaran adalah acuan pembelajaan yang dilaksanakan berdasarkan pola-pola pembelajaran tertentu secara sistematis. Model pembelajaran dapat dibedakan menjadi empat macam, yaitu model pembelajaran interaksional, model pemrosesan informasi, model personal, dan model pembelajaran modifikasi tingkah laku dan lain-lain (Prastowo, 2013: 73-74).

Model pembelajran adalahkerangka konseptual yang melukiskan prosedur yang sistematis dalam mengoraganisasikan pengalaman belajar untuk mencapai tujuan tertentu dan berfungsi sebagai pedoman bagi para perancang pembelajaran dan para pengajar dalam merencanakan aktivitas belajar-mengajar. Jadi, model pembelajaran adalah seperangkat prosedur yang sistematis sebagai perancang bagi para pengajar untuk mencapai tujuan belajar.

\section{Model Pembelajaran Concept Sentence}

Concept sentence pada hakikatnya merupakan pengembangan dari concept attainment. Inti dari concept attainment adalah bagaimana siswa mampu mencari dan mendaftar atribut-atribut yang dapat digunakan untuk membedakan contohcontoh yang tepat dari yang tidak tepat. Esensi concept attainment pada hakikatnya tidak jauh berbeda dengan concept sentence dimana pembelajaran ini berusaha 
mengajarkan siswa untuk membuat sebuah kalimat dengan beberapa kata kunci yang telah disediakan agar bisa menangkap konsep yang terkandung dalam kalimat tersebut dan membedakannya dengan kalimat-kalimat yang lain.

Dalam praktiknya, concept sentencemerupakan strategi pembelajaran yang dilakukan dengan memberikan kartu-kartu yang berisi beberapa kata kunci kepada siswa, kemudian kata kunci-kata kunci tersebut disusun menjadi beberapa kalimat dan dikembangkan menjadi paragraf-paragraf. Model ini dilakukan dengan mengelompokkan siswa secara heterogen dan meminta mereka untuk membuat kalimat dengan minimal 4 kata kunci sesuai dengan materi yang disajikan.

Concept sentence merupakan model pembelajaran yang diawali dengan penyampaian kompetensi, sajian materi, pembentukan kelompok heterogen, penyajian kata kunci sesuai materi bahan ajar, dan penugasan kelompok. Prosedur selanjutnya dalam pembelajaran ini adalah mempresentasikan hasil belajar secara bergantian di depan kelas (Huda, 2013: 315-316).

Sintak pembelajaran ini bisa diterapkan dengan mengikuti langkah-langkah sebagai berikut ini.

1. Guru menyampaikan kompetensi yang akan dicapai.

2. Guru menyajikan materi terkait dengan pembelajaran secukupnya.

3. Guru membentuk kelompok yang anggotanya kurang lebih 4 orang secara heterogen.

4. Setiap setiap siswa dalam kelompok diminta untuk membuat beberapa kalimat dengan menggunakan minimal 4 kata kunci setiap kalimat.

5. Siswa dibantu guru memberikan kesimpulan.

Salah satu contoh model pembelajaran dengan concept sentence adalah pembelajaran flash card. flash card atau education card adalah kartu-kartu bergambar yang dilengkapi kata-kata, yang diperkenalkan oleh Glenn Doman (1994).

Terdapat beberapa kelebihan strategi pembelajaran Concept sentence. Kelebihan Concept sentence tersebut meliputi: (1) meningkatkan semangat belajar siswa, (2) memunculkan kegembiraan belajar, (3) membantu tersedia pembelajaran yang kondusif, (4) mendorong dan mengembangkan proses berpikir kreatif, (5) mendorong siswa untuk memandang sesuatu dalam pandangan yang berbeda, (6) memunculkan kesadaran untuk berubah menjadi lebih baik, (7) memperkuat kesadaran diri, dan (8) lebih memahami kata kunci dari materi pokok pelajaran. Kelemahan strategi pembelajaran ini adalah (1) hanya untuk mata pelajaran tertentu, (2) kecenderungan siswa yang pasif untuk mengambil jawaban dari temannya. 


\section{METODE}

Penelitian ini menggunakan metode "Classroom Action Research" yang disingkat CAR atau penelitian tindakan kelas (PTK). Pendekatan yang digunakan adalah deskriptif kualitatif. Menurut Nazir (1988:63) (dalam Prastowo, 2011:186), metode deskriptif adalah suatu metode yang digunakan untuk meneliti status sekelompok manusia, suatu objek, suatu set kondisi, suatu sistem pemikiran, ataupun suatu kelas peristiwa pada masa sekarang. Subjek penelitian ini adalah seluruh siswa kelas III SDN Kelas III SDN 20 Halmahera Barat, Kecamatan Sahu Barat yang berjumlah 17 siswa, ditambah guru bahasa dan sastra Indonesia. Teknik pengumpulan data dalam penelitian tindakan kelas ini dilakukan dengan (1) pengamatan, (2) wawancara, dan (3) tes. Prosedur penelitian mencakup: (1) perencanaan tindakan yang akan digunakan, (2) pelaksanaan tindakan, (3) observasi, dan (4) refleksi hasil tindakan yang telah dilakukan.

\section{PEMBAHASAN}

\section{Hasil}

\section{a. Temuan siklus 1}

Hasil temuan siklus I kemampuan guru menerapkan model concept sentenceberdasarkan hasil di atas setiap indikator akan dirinci secara jelas sebagai berikut:

Tabel 1. Hasil Aktivitas Guru Menerapkan Model Concept Sentence Siklus I

\begin{tabular}{|c|c|c|c|c|c|c|c|}
\hline \multirow[t]{2}{*}{ No } & \multirow[t]{2}{*}{ Keterampilan Guru } & \multicolumn{4}{|c|}{ Skala nilai } & \multirow{2}{*}{$\begin{array}{l}\text { Jumlah } \\
\text { skor }\end{array}$} & \multirow[t]{2}{*}{ Kriteria } \\
\hline & & 1 & 2 & 3 & 4 & & \\
\hline 1 & Membuka pelajaran dengan apersepsi & & $\sqrt{ }$ & & & 2 & $\mathrm{C}$ \\
\hline 2 & Melaksanakan tanya jawab dengan siswa & & & $\sqrt{ }$ & & 4 & B \\
\hline 3 & $\begin{array}{l}\text { Menjelaskan cara menulisparagraf } \\
\text { menggunakan model concept sentence }\end{array}$ & & & $\sqrt{ }$ & & 3 & B \\
\hline 4 & $\begin{array}{l}\text { Membimbing siswa dalam menulis paragraf } \\
\text { dengan model concept sentence }\end{array}$ & & & $\sqrt{ }$ & & 3 & B \\
\hline 5 & Menutup pelajaran & & & & $\sqrt{ }$ & 2 & $\mathrm{C}$ \\
\hline
\end{tabular}

1) Membuka Pelajaran dengan Apersepsi. Indikator apersepsi guru mendapatkan skor 2. Pada indikator ini guru belum maksimal melakukan apersepsi, dengan kata lain guru langsung masuk pada pelaksanaan pembelajaran. Belum 
bertanya pada siswa tentang materi pembelajaran, juga tentang menulis paragraf.

2) Melaksanakan Tanya Jawab dengan Siswa. Guru telah melakukan tanya jawab tentang paragraf deskripsi, memindahkan giliran menjawab pada siswa, dan bersama siswa menyimpulkan paragraf deskripsi, akan tetapi pada tahap ini guru belum membuat siswa bertanya. Tahap ini observer memberikan nilai $\mathrm{C}$ atau kategori cukup.

3) Menjelaskan cara menulisparagraf menggunakan model concept sentence. Tahapan ini guru harus menjelaskan secara rinci bagaimana cara menyambungkan kata, termasuk penggunaan tanda baca, dan kata penghubung. Guru mendekati siswa dan menjelaskan secara rinci, sehingga siswa dapat menulis paragraf dengan baik. Sesuai hasil amatan, guru telah melakukan tindakan ini, tetapi belum maksimal. Tahapan ini guru mendapat kriteria B.

4) Membimbing siswa dalam menulis paragraf dengan model concept sentence. Guru dalam menerapkan model concept sentence sebagaimana diamati belum melakukan bimbingan secara merata antara siswa yang satu dengan yang lain. Mengakibatkan masih banyak siswa yang belum data menulis paragraf, karena bimbingan dari guru yang masih kurang. Tahap ini juga tahap dimana guru memberikan motivasi dan apresiasi, menunjukan kekurangan yang dilakukan oleh setiap guru. Tahap ini mendapatkan kriteria B.

5) Menutup Pelajaran. Sesuai dengan amatan observer, guru pada tahap ini telah melakukannya dengan baik, tetapi belum menyimpulkan materi yang telah disampaikan. Oleh sebab itu, skor yang diberikan adalah B.

Hasil temuan aktivitas siswa siklus I dilihat pada aktivitas siswa masih berada pada kategori yang berbeda pada setiap aktivitas. Aktivitas pertama, mendapat skor 2 (Cukup); kedua, skor 2 (Cukup); ketiga, mendapat skor 1 (Kurang); keempat, masih pada skor 3 (Baik); dan kelima, umumnya siswa masih memperoleh skor 1 (Kurang). Oleh karena itu, hasil ini belum adanya keberhasilan siswa dalam mengikuti proses pembelajara menulis paragraf melalui model concept sentence.

Tabel 2. Data Hasil Menulis Paragraf Bahasa Indonesia Siklus I

\begin{tabular}{|c|c|c|l|}
\hline No. & Nama Siswa & Nilai & \multicolumn{1}{|c|}{ Keterangan } \\
\hline 1. & BS & 66 & belum mencapai KKM \\
\hline 2. & SC & 59 & belum mencapai KKM \\
\hline 3. & AM & 68 & belum mencapai KKM \\
\hline
\end{tabular}




\begin{tabular}{|c|c|c|l|}
\hline 4. & SU & 67 & belum mencapai KKM \\
\hline 5. & A.T & 73 & mencapai KKM \\
\hline 6. & RW & 67 & belum mencapai KKM \\
\hline 7. & KS & 75 & belum mencapai KKM \\
\hline 8. & OM & 73 & belum mencapai KKM \\
\hline 9. & PS & 74 & belum mencapai KKM \\
\hline 10. & MR & 74 & belum mencapai KKM \\
\hline 11. & S.U & 71 & belum mencapai KKM \\
\hline 12. & UD & 71 & belum mencapai KKM \\
\hline 13. & LB & 76 & mencapai KKM \\
\hline 14. & IG & 69 & belum mencapai KKM \\
\hline 15. & ZL & 74 & belum mencapai KKM \\
\hline 16. & HF & 73 & belum mencapai KKM \\
\hline 17. & JS & 71 & belum mencapai KKM \\
\hline
\end{tabular}

Nilai yang diperoleh siswa terkait dengan kemampuan menulis bahasa Indonesia dengan model concept sentence belum menunjukkan peningkatan yang signifikan. Nilai tertinggi yang diperoleh siswa hanya 76 sementara nilai terendahnya 60, sementara nilai KKM mata pelajaran bahasa Indonesia adalah 75 . Untuk itu, pelaksanaan pembelajaran dengan model concept sentence lebih diintensifkan lagi, agar semua siswa dapat menulis cerpen dengan baik.

Umumnya siswa belum dapat memusatkan pada aspek objek yang ditulis, pilihan kata belum maksimal, tanda baca, kerapian tulisan. Rata-rata pada aspek ini siswa belum mencapai KKM. Sebanyak 9 siswa memperoleh nilai rata-rata 5059\%; 5 siswa memperoleh nilai rata-rata 60-78\%; dan 3 siswa memperoleh nilainilai $80 \%$ atau mencapai KKM.

Tabel 2. Data Hasil Aktivitas Menulis Paragraf Siswa Dengan Model Concept Sentence Siklus 1

\begin{tabular}{|c|c|c|c|c|c|c|c|}
\hline \multirow{2}{*}{ No } & \multirow{2}{*}{ Indikator } & \multicolumn{4}{|c|}{ Skor Penilaian } & \multirow{2}{*}{$\begin{array}{c}\text { Jumlah } \\
\text { Skor }\end{array}$} & \multirow{2}{*}{ Kriteria } \\
\hline & & 1 & 2 & 3 & 4 & & \\
\hline 1 & $\begin{array}{l}\text { Siswa menyiapkan diri untuk mengikuti } \\
\text { pembelajaran }\end{array}$ & & $\sqrt{ }$ & & & 2 & $\mathrm{C}$ \\
\hline 2 & Siswa mendengarkan penejelasan guru & & $\sqrt{ }$ & & & 2 & $\mathrm{~K}$ \\
\hline 3 & Siswa membuat concept sentence & $\sqrt{ }$ & & & & 3 & $\mathrm{C}$ \\
\hline 4 & $\begin{array}{l}\text { Siswa menulis paragraf melalui model } \\
\text { concept sentence }\end{array}$ & & & $\sqrt{ }$ & & 3 & $\mathrm{C}$ \\
\hline 5 & $\begin{array}{l}\text { Siswa mengumpulkan hasil karangan } \\
\text { secara tertib dan tepat waktu. }\end{array}$ & $\sqrt{ }$ & & & & 1 & $\mathrm{~K}$ \\
\hline
\end{tabular}




\section{Temuan siklus II:}

Tabel 3. hasil aktivitas guru menerapkan model concept sentence siklus ii

\begin{tabular}{|c|c|c|c|c|c|c|c|}
\hline \multirow[t]{2}{*}{ No } & \multirow{2}{*}{ Keterampilan guru } & \multicolumn{4}{|c|}{ Skal nilai } & \multirow{2}{*}{$\begin{array}{c}\text { Jumlah } \\
\text { skor }\end{array}$} & \multirow{2}{*}{ Kriteria } \\
\hline & & 1 & 2 & 3 & 4 & & \\
\hline 1 & Membuka pelajaran dengan apersepsi & & & $\sqrt{ }$ & & 3 & B \\
\hline 2 & Melaksanakan tanya jawab dengan siswa & & & & $\sqrt{ }$ & 4 & A \\
\hline 3 & $\begin{array}{l}\text { Menjelaskan cara menulisparagraf menggunakan } \\
\text { model concept sentence }\end{array}$ & & & $\sqrt{ }$ & & 3 & B \\
\hline 4 & $\begin{array}{l}\text { Membimbing siswa dalam menulis paragraf } \\
\text { dengan model concept sentence }\end{array}$ & & & & $\sqrt{ }$ & 4 & A \\
\hline 5 & Menutup pelajaran & & & & $\sqrt{ }$ & 4 & A \\
\hline
\end{tabular}

Berdasarkan tabel di atas, terlihat adanya perbedaan atau peningkatan aktivitas mengajar guru jika dibandingkan dengan siklus I. Semua aktivitas telah berjalan sesuai dengan perencanaan pembelajaran. Semua tahapan pembelajaran oleh guru sudah mencapai skor 4 (Baik), kecuali pada tahapan membuka pelajaran dengan apersepsi. Namun demikian, pada tahap juga telah mengalami peningkatan jika dibandingkan siklus I.

Peningkatan aktivitas pembelajaran menulis paragraf ini juga terlihat pada aktivitas siswa. Di mana adanya perbedaan yang siginifikan antara siklus I dan II. Hal ini dapat dilihat pada tabel di bawah.

Tabel 4. Hasil Aktivitas Menulis Paragraf Siswa dengan Model Concept Sentence Siklus II

\begin{tabular}{|c|l|c|c|c|c|c|c|}
\hline \multirow{2}{*}{ No } & \multicolumn{1}{|c|}{ Indikator } & \multicolumn{1}{|c|}{ Skor Penilaian } & \multicolumn{1}{|c|}{$\begin{array}{c}\text { Jumlah } \\
\text { Skor }\end{array}$} & Kriteria \\
\hline 1 & $\begin{array}{l}\text { Siswa menyiapkan diri untuk mengikuti } \\
\text { pembelajaran }\end{array}$ & & $\sqrt{ }$ & & 2 & $\mathrm{C}$ \\
\hline 2 & Siswa mendengarkan penejelasan guru & & & & $\sqrt{ }$ & 2 & $\mathrm{C}$ \\
\hline 3 & Siswa membuat concept sentence & & & $\sqrt{ }$ & & 3 & $\mathrm{~K}$ \\
\hline 4 & $\begin{array}{l}\text { Siswa menulis paragraf melalui model } \\
\text { concept sentence }\end{array}$ & & & $\sqrt{ }$ & 3 & $\mathrm{C}$ \\
\hline 5 & $\begin{array}{l}\text { Siswa mengumpulkan hasil karangan } \\
\text { secara tertib dan tepat waktu. }\end{array}$ & & & $\sqrt{ }$ & 1 & $\mathrm{~K}$ \\
\hline
\end{tabular}

Aktivitas menulis paragraf di atas, dapat dijelaskan bahwa terjadinya peningkatan aktivitas belajar siswa jika dibandingkan dengan siklus I. Hal ini disebabkan setiap indikator yang diamatai telah mengalami peningkatan. Indikator pertama pada siklus I berada pada skor 2 (Cukup), meningkat menjadi 3 (Baik). 
Hal yang sama terjadi pada indikator yang lain, di mana pada siklus I berada pada skor 3, pada siklus II meningkat menjadi 4 (Sangat Baik).

Proses pembelajaran pada tahap siklus II berlangsung dengan lancar, meskipun masih ada beberapa siswa yang terlihat masih agak kesulitan dalam menyusun pemetaan pikiran. Siswa sudah mampu menuliskan kata-kata menjadi paragraf yang sederhana dibanding siklus I.

Pada siklus I, hasil yang dicapai siswa belum ada yang mencapai nilai 80, dan secara klasikal rata-rata nilai yang diperoleh siswa adalah 71. Akan tetapi, pada siklus II nilai tertinggi yang diperoleh siswa sudah mencapai 85. Secara klasikal nilai yang diperoleh siswa adalah 80 . Angka ini berada pada kategori baik. Selanjutnya, jika dilihat dari nilai KKM perolehan nilai secara klasikal melampaui standar ketuntasan minimal, yakni 80 .

Tabel 5. Hasil Aktivitas Siswa Menulis Paragraf Siklus II

\begin{tabular}{|c|c|c|c|}
\hline No. & Nama Siswa & Nilai & Keterangan \\
\hline 1. & $\mathrm{BS}$ & 67 & melampaui KKM \\
\hline 2. & $\mathrm{SC}$ & 76 & melampaui KKM \\
\hline 3. & AM & 79 & melampaui KKM \\
\hline 4. & $\mathrm{SU}$ & 76 & mencapai KKM \\
\hline 5. & A.T & 81 & melampaui KKM \\
\hline 6. & RW & 82 & melampaui KKM \\
\hline 7. & $\mathrm{KS}$ & 82 & melampaui KKM \\
\hline 8. & $\mathrm{OM}$ & 84 & melampaui KKM \\
\hline 9. & PS & 77 & melampaui KKM \\
\hline 10. & MR & 74 & mencapai KKM \\
\hline 11. & S.U & 73 & mencapai KKM \\
\hline 12. & UD & 74 & mencapai KKM \\
\hline 13. & LB & 77 & melampaui KKM \\
\hline 14. & IG & 82 & melampaui KKM \\
\hline 15. & $\mathrm{ZL}$ & 83 & melampaui KKM \\
\hline 16. & $\mathrm{HF}$ & 81 & melampaui KKM \\
\hline 17. & JS & 74 & mencapai KKM \\
\hline
\end{tabular}


Umumnya siswa belum dapat memusatkan pada aspek objek yang ditulis, pilihan kata belum maksimal, tanda baca, kerapian tulisan. Rata-rata pada aspek ini siswa belum mencapai KKM. Sebanyak 9 siswa memperoleh nilai rata-rata 5059\%; 5 siswa memperoleh nilai rata-rata $60-78 \%$; dan 3 siswa memperoleh nilainilai $80 \%$ atau mencapai KKM.

\section{Pembahasan}

Penggunaan model concept sentence dalam pembelajaran menulis paragraf bahasa Indonesia memberikan kesempatan kepada siswa untuk memperoleh bimbingan dan arahan dalam setiap menulis yang dilalui. Bimbingan dan arahan yang diberikan guru dapat membantu siswa dalam mengembangkan kemampuan mereka dalam menulis, sekaligus membantu mencari jalan keluar terhadap permasalahan yang ditemui pada waktu kegiatan menulis berlangsung.

Adapun saat itu siswa tidak dipaksa atau diperintah untuk mengikuti apa yang telah dikemukakan guru, mereka bebas berimajinasi untuk mengungkapkan gagasannya sesuai dengan minat, pengalaman, dan pengetahuan yang dimilikinya. Ide siswa digali dalam bentuk kata-kata kunci yang dirangkai.

\section{SIMPULAN}

Peningkatan pada setiap tahapan ini diuraikan berikut: pertama, capaian pada saat menulis paragraf dari kata-kata yang tulis yang divisualisasikan terlebih dahulu melalui kata-kata kunci. Peningkatan kemampuan siswa pada menulis dapat dilihat dari kemampuan siswa menulis paragraf bahasa Indonesia dengan kata-kata yang telah ditulisnya. Peningkatan kemampuan siswa adalah siswa dapat menemukan kesalahan-kesalahan dalam tulisan. Selain itu, pada tahap ini memberikan kesempatan yang besar bagi siswa berlatih menyunting tulisan dan menilai sendiri tentang kemampuannya dalam menulis paragraph; kedua, hasil analisis kemampuan siswa menulis paragraf bahasa Indonesian terlihat terutama pada siklus II, secara klasikal nilai rata-rata yang diperoleh siswa mencapai 80 . Angka ini berdada pada ketegori baik. Jika dihubungkan dengan nilai KKM sebagai standar ketuntasan hasil belajar, nilai yang diperoleh siswa secara klasikal melampaui standard ketuntasan minimal yang ditentukan, yaitu 80 . 


\section{DAFTAR PUSTAKA}

Akhadiah., S. Arsjad, M.G., Ridwan. 1994. Pembinaan Kemampuan Menulis bahasa Indonesia. Jakarta: Erlangga.

Buzan, T. 2006. Buku Pintar Mind Map. Terjemahan oleh Susi Purwoko. Batam: Interaksara.

Dalman. 2012. Menulis Karya Ilmiah. Jakarta: Raja Grafindo Persada.

Depdiknas. 2002.Kurikulum Berbasis Kompetensi. Jakarta: Pusat Kurikulum, Balit-bang Depdiknas.

Naim, Ngainum. 2011. Menjadi Guru Inspiratif. Yogyakarta: Pustaka Pelajar.

Prastowo, Andi. 2011. Metode Penelitian Kualitatif: Dalam Perspektif Rancangan Penelitian.Jogjakarta: Ar-Ruzz Media.

-------------. 2013. Pengembangan Bahan Ajar Tematik. Jogjakarta: DIVA Press.

Saddhono, Kundharu., Slamet, Y. 2012. Meningkatkan Keterampilan Berbahasa Indonesia; Teori dan Aplikasi. Bandung: Karya Putra Darwati.

Subana, M., Sunarti. 2011. Strategi Belajar Mengajar Bahasa Indonesia: Berbagai Pendekatan, Metode, Teknik, dan Media Pengajaran. Bandung: CV Pustaka Setia.

Sugiyono. 2007. Metode Penelitian Pendidikan Pendekatan Kuantitatif, Kualitatif dan $R \& D$. Bandung: Alfabeta.

Subana, M., Sunarti. 2011. Strategi Belajar Mengajar Bahasa Indonesia: Berbagai Pendekatan, Metode, Teknik, dan Media Pengajaran. Bandung: CV Pustaka Setia.

Suyudi. 2013. Panduan Penelitian Tindakan Kelas: cetakan ke IX. Jogjakarta: Diva Press.

Widjono. 2012. Bahasa Indonesia: Mata Kuliah Pengembangan Kepribadian di Perguruan Tinggi. Jakarta: PT Gramedia. 